\title{
Frontiers
}

\section{in the Psychotherapy} of Trauma \& Dissociation

\section{Recovered Memories of Child} Sexual Abuse: Forgetting to Remember and Remembering to Forget, Part 1: A Perennial Controversy

Sylvia Solinski, Consultant Psychiatrist

The Official Clinical Journal of the International Society for the Study of Trauma and Dissociation 


\title{
Frontiers in the Psychotherapy of Trauma \& Dissociation
}

The Official Clinical Journal of the ISSTD

\section{EDITOR}

ANDREAS LADDIS, MD, Private Practice and Faculty, Boston University, School of Public Health, Boston, Massachusetts, USA

\author{
ASSOCIATE EDITOR \\ MARTIN J DORAHY, PhD, Professor, Department of Psychology, University of Canterbury, \\ Christchurch, New Zealand and The Cannan Institute, Brisbane, Australia
}

\section{EDITORIAL ASSISTANT}

COURTENAY CRUCIL, MA, RCC, Private Practice, Terrace, British Columbia, Canada

\begin{abstract}
Frontiers in the Psychotherapy of Trauma $\mathcal{E}$ Dissociation is published by the International Society for the Study of Trauma and Dissociation, Inc., 4201 Wilson Blvd Third Floor, Arlington, VA 22203
\end{abstract}

\section{Annual Subscription, Volume 4, 2020}

Online subscription is part of the membership dues of the International Society for the Study of Trauma and Dissociation. Visit https://www.isst-d.org/join-isstd/individualmember-benefits/.

Production and Advertising Office: ISSTD Headquarters, 4201 Wilson Blvd Third Floor, Arlington, VA 22203

Copyright $\odot 2020$ International Society for the Study of Trauma and Dissociation. All rights reserved. No part of this publication may be reproduced, stored, transmitted, or disseminated in any for or by any means without prior written permission from the International Society for the Study of Trauma and Dissociation. The publisher assumes no responsibility for any statements of fact or opinion expressed in the published papers. The appearance of advertising in this journal does not constitute an endorsement or approval by the publisher, the editor, the editorial board, or the board of directors of the International Society for the Study of Trauma and Dissociation of the quality or value of the product advertised or of the claims made of it by its manufacturer.

Subscriptions to this journal are acquired through membership in the International Society for the Study of Trauma and Dissociation only.

Visit https://www.isst-d.org/join-isstd/individual-memberhip-categories/.

Permissions. For further information, please write to info@isst-d.org.

\section{EDITORIAL BOARD}

ELIZABETH S BOWMAN, MD, Editor Emerita, Journal of Trauma \& Dissociation, Adjunct Professor of Neurology, Indiana University School of Medicine, Indianapolis, Indiana, USA

LAURA S. BROWN, PhD, Private Practice, Seattle, Washington, USA

RICHARD A CHEFETZ, MD, Private Practice, Faculty and Founding Member Institute of Contemporary Psychotherapy \& Psychoanalysis, Distinguished Visiting Lecturer: William Alanson White Institute of Psychiatry, Psychoanalysis \& Psychology, New York City, USA

CONSTANCE J DALENBERG, PhD, Trauma Research Institute, California School of Professional Psychology, San Diego, California, USA

J.K. JUDITH DANIELS, PhD, Faculty of Behavioural and Social Sciences, University of Groningen, The Netherlands

STEVEN N GOLD, PhD, Professor, Center for Psychological Studies, and Founding Director, Trauma Resolution \& Integration Program, Nova Southeastern University, Fort Lauderdale, Florida, USA ELIZABETH B HEGEMAN, PhD, Professor, Department of Anthropology, John Jay College of Criminal Justice, New York, New York, USA 
RICHARD P. KLUFT, MD, PhD Private Practice and Clinical Professor of Psychiatry, Temple University School of Medicine; Faculty Member, Philadelphia Center for Psychoanalysis,

Philadelphia, Pennsylvania, USA

CHRISTA KRÜGER, MD, Professor of Psychiatry, University of Pretoria, Pretoria, Gauteng, South Africa

KARLEN LYONS-RUTH, PhD, Professor of Psychology, Harvard Medical School, Cambridge, Massachusetts, USA

ALFONSO MARTÍNEZ-TABOAS, PhD, Professor, Albizu University, San Juan, Puerto Rico WARWICK MIDDLETON, MD, Adjunct Professor, Cannan Institute, Brisbane, Australia

ELLERT R. S. NIJENHUIS, PhD, Department of Psychiatry and Outpatient Department Mental Health Care Drenthe, Assen, The Netherlands

SANDRA PAULSEN, PhD, Bainbridge Institute for Integrative Psychology, Bainbridge Island, Washington, USA

VEDAT SAR, MD, Professor of Psychiatry, Koç University School of Medicine (KUSOM), Istanbul, Turkey

JOYANNA SILBERG, PhD, Trauma Disorders Program, Sheppard Pratt Health Systems, Baltimore, Maryland, USA

ELI SOMER, PhD, Professor, School of Social Work, University of Haifa, Israel

KATHY STEELE, MN, CS, Private Practice, Atlanta, Georgia, USA

ONNO VAN DER HART, PhD Emeritus Professor of Psychopathology of Chronic Traumatization, Department of Clinical and Health Psychology, Utrecht University, Utrecht, The Netherlands VICTOR WELZANT, PsyD, Sheppard Pratt Health Systems, Trauma Disorders Program

\section{REVIEWERS}

JOHN BRIERE, PhD, Associate Professor of Psychiatry and Psychology, University of Southern California Keck School of Medicine, Los Angeles, California, USA

SHELDON IZKOWITZ, PhD, Clinical Associate Professor of Psychology and Clinical Consultant, Postdoctoral Program, New York University, New York City, USA and Teaching Faculty \& Supervisor of Psychotherapy and Psychoanalysis, National Institute for Psychotherapies, New York City, USA

MARY-ANNE KATE, PhD Researcher at University of New England, Australia; University of New England, New South Wales, Australia

ULRICH F. LANIUS, PhD, Private Practice, West Vancouver, British Columbia, Canada

\section{SUPPORTERS}

ISSTD thanks its generous supporters whose contributions have made this publication possible:

Andreas Laddis, MD, USA

\section{The \\ Cannan \\ Institute}

Cannan Institute, Australia

Warwick Middleton, MD, Australia

Dana Ross, MD, Canada

Martin J. Dorahy, PhD, New Zealand

Kate McMaugh, Australia

Sara Y. Krakauer, USA

Paula Eagle, MD, USA 


\title{
ARTICLE
}

\section{RECOVERED MEMORIES OF CHILD SEXUAL ABUSE: FORGETTING TO REMEMBER AND REMEMBERING TO FORGET, PART 1: A PERENNIAL CONTROVERSY}

\author{
SYLVIA SOLINSKI, Consultant Psychiatrist \\ Malvern Psychotherapy Centre, 1232 Malvern Road, \\ Malvern, VIC 3144, Australia
}

This is the first of three articles on recovered memories of child sexual abuse. The controversy regarding recovered memories of sexual abuse is perennial and numerous clinical studies document the phenomenon. Study designs are variable and a number of methodological issues are explored. The recovery of memory is independent of the veracity of memory and there is consensus among a range of professional organizations that recovered memories are a valid entity. The second and third articles examine various approaches to elucidating the nature of memory and how it is affected by traumatic events.

KEYWORDS controversy; methodology; veracity; consensus

\section{INTRODUCTION}

Recovered memories of traumatic events have long been documented in a diverse range of populations. These include survivors of natural disasters and accidents (Janet, 1889, as cited in Van der Hart, Steele, Boon, \& Brown, 1993; Madakasira \& O’Brian, 1987; Wilkinson, 1983), soldiers exposed to

Acknowledgements: The author is grateful to Martin Dorahy and Andreas Laddis for their help in the preparation of this paper.

Correspondence: Dr. Sylvia Solinski, 5 Mowbray Street, Hawthorn East, VIC 3123, Australia. Email: sylviasolinski@iinet.net.au. 
combat (Grinker \& Spiegel, 1945; Kardiner, 1941; Myers, 1915; Sargant \& Slater, 1941; Thom \& Fenton, 1920; Van der Kolk, 1987), victims of kidnapping, torture and concentration camp incarceration (Goldfeld, Mollica, Pesavento, \& Faraone, 1988; Kinzie, 1993; Kuch \& Cox, 1992) and convicted murderers (Schacter, 1986). In 1980, in the wake of reported memory disruptions (both amnesia and flashbacks) in Vietnam veterans, psychological trauma was officially recognized and introduced into the Diagnostic and Statistical Manual of Mental Disorders-III (American Psychiatric Association, 1980) as posttraumatic stress disorder (PTSD).

It should, by now, be uncontroversial that recovered memory (RM) is also observed in people who report a history of child sexual abuse (CSA). However, historically it has generated acrimonious debate (Freud, 1896, as cited in Masson, 1984) and continues to do so.

\section{Why the Controversy?}

Estimates of the prevalence of CSA indicate that, while it is high (PérezFuentes et al., 2013) it is likely that many factors including under-detection and under-reporting lead to the phenomenon of the "tip of the iceberg" (MacMillan, Jamieson, \& Walsh, 2003) whereby many victims remain unrecognized. Despite Finkelhor's (1994) finding that, across all CSA studies, only about half of victims had disclosed the abuse to anyone, epidemiological studies indicate that it affects more than 1 out of 5 women and one out of 10 men worldwide (Collin-Vézina, Daigneault, \& Hébert, 2013). Western society has a long history of denial of such abuse. Moreover, it seems that there is "a significant investment in the myth of dishonest, suggestible or hysterical women who report CSA and in the stereotype of the vindictive feminist seeking to destroy men and the family" (Cossins, 1997, p. 31). In 1992 the False Memory Syndrome Foundation (FMSF) was formed as a support group for parents who claimed to have been falsely accused of abusing their children. It attracted eminent clinicians and academics (not all of whom were experts on memory) who served as board members and acted as advisors, and it identified media coverage as a key objective. Sociologist Katherine Beckett documented the shift in public opinion by analyzing the content of a cross section of popular media; in 1991, 80\% of articles on CSA were sympathetic toward the survivors of alleged abuse whereas by $1994,80 \%$ of articles highlighted the supposedly false nature of memories of abuse (Beckett, 1996).

In a critique of the FMSF, Pope (1996) noted both the dearth of empirical evidence and the preponderance of ideology that premised the claims of a false memory syndrome. Notwithstanding, "false memory" became the subject of academic and legal debate (Alpert et al., 1996). During the past twenty years there has been an unprecedented growing awareness and public exposure of the enormity of CSA. The systemic and organized nature of 
the networks that spawn and maintain such abuse is insidious and sophisticated, and the extent of their power, influence, and ability to function with impunity is widespread (Middleton et al., 2013; Middleton, 2015).

Attempts to empirically undermine RM have framed the debate in terms of "repression." The argument draws on a study by Holmes (1990) in which he reviewed 5 experimental strategies designed to investigate repression and concluded that other mechanisms could equally well have explained the results. Holmes's article has been frequently cited as evidence to discredit recovered memories but, as Gleaves and Freyd (1997) point out, his work investigates mechanisms for repression, not the phenomenon of memory inaccessibility, and Holmes himself did not claim that the failure to demonstrate repression invalidates the possibility of RM. In effect, the attempt to repudiate repression as the purported mechanism for amnesia is a logically fallacious straw man argument.

There is a longstanding divide between cognitive science research and clinical psychology and psychiatry. The fields have differed with respect to samples, methodologies, observations and hypotheses regarding the nature of memory. Laboratory tested experimental paradigms yield results that are at odds with the vicissitudes of memory that are encountered by clinicians. As DePrince et al. (2012) note: "How do you measure a memory that is not accessible (or was never encoded) for a private event that was not witnessed by anyone but the perpetrator, as is the case for many abuse experiences? Who are the best participants for studies on forgetting and misremembering: people who report having forgotten and now remember; people who we have some reason to believe they were abused and now forget; or another group altogether?" (p. 196).

\section{Studies of Recovered Memory of Sexual Abuse}

There are more than 75 studies that report amnesia related to CSA (Brewin, 2012; Brown, Scheflin, \& Whitfield, 1999; DePrince et al., 2012; Scheflin \& Brown, 1996; Silberg, 2013; Sivers, Schooler, \& Freyd, 2002). These include survey studies on clinical, non-clinical (targeted) and random (nontargeted) populations, prospective studies on individuals with documented abuse experiences, and case studies.

A large number of salient methodological issues challenge investigations of recovered memory. These include the following:

a) Studies that investigate patients survey individuals whose experience in current or past therapy may have influenced their beliefs about what they have forgotten and remembered. Studies that attempt to address this (e.g., Gold, Hughes, \& Swingle, 1999) collect data on sexual abuse in an initial interview prior to therapy, but may not indicate whether there is a past history of therapy. Moreover, these studies may reflect a sample bias in that patients are self-selected seekers of intervention. However, these are 
often individuals who have experienced high levels of trauma and are more symptomatic.

b) Irrespective of population characteristics or method of recruitment, all retrospective studies suffer from reliance on self-reports. Memory for even trivial personal events is not objective; childhood memories in particular are subject to elaboration and interpretation (Sloutsky \& Fisher, 2004), events that are remembered may, for various reasons, be omitted and experiments demonstrate the frequency of misremembering details even when the central event is correctly remembered (Loftus, 1975). Moreover, many traumatized individuals may have trouble remembering even the central details of their experience for variable periods of time (Brown, Scheflin, \& Hammond, 1998).

c) Prospective studies (Burgess, Hartman, \& Baker, 1995; Ghetti et al., 2006; Goodman et al., 2003; Widom \& Morris, 1997; Williams, 1995) attempt to address the issue of memory accuracy by identifying individuals whose abuse has been corroborated and whose memory for it is tested at follow-up. Evidence that may be deemed corroborative varies and is of differing probative value. Couacaud (1999, as cited in DePrince et al., 2012) categorized corroboration according to the degree of external validation potentially available. High levels of corroboration included documentary evidence such as police, medical, and court records. Medium levels of corroboration included statements from family or friends regarding their contemporaneous knowledge of the abuse. Evidence that others were abused by the perpetrator was considered to be of low corroborative value.

d) As Freyd (1998) has noted, memory accuracy and memory accessibility are conceptually distinct; inaccurate memories may be continuously available and accurate memories may be unavailable for varying periods of time. It has been argued (Pope, Oliva, \& Hudson, 1999) that RM research should include a clarification interview and not merely a free recall interview; unless individuals are specifically told about their abuse and asked why they did not remember it, it is difficult to ascertain whether they actually forgot it. Scheflin and Brown (1996) note: "False memory advocates try to have it both ways: first they claim that therapy interviews are unduly suggestive to the point of implanting false memories, and then they claim that research interviews are "clarifying," with the implication that research interviews are somehow free from suggestive effects while therapy interviews are not" (p. 171). Furthermore, aside from the problematic nature of retrospective memory judgments in general (Bradburn, Rips, \& Shevell, 1987; Henry, Moffitt, Caspi, Langley, \& Silva, 1994), it is paradoxical to ask people to evaluate their past ability to recollect an event during a period when, inter alia, for reasons of self-protection they may not have recalled that event (Dalenberg, 1996; Read, 1997; Schooler, 1994). This is compounded by the inability of individuals to report on their unconscious processes (Wilson, 2002). 
Sivers et al. (2002) point out another limitation of prospective studies: "The evidence that they provide for forgetting only applies to those memories that were not recalled at the time of the interview. Since the recovered memories identified in these studies were recalled during the interview, these studies do not speak to the degree to which recovered memories are ever fully forgotten" (p. 173). Indeed, as discussed below, individuals may believe that they forgot something for which, in fact, they demonstrated awareness.

e) Finally, a limitation of the collective research is that data is aggregated across cases. Salient details of individual cases that potentially elucidate the phenomenon may be obscured. This shortcoming is addressed by detailed analysis of individual case studies that provide impressive evidence to substantiate individuals' recovered memories of abuse (Schooler, Ambadar, \& Bendiksen, 1997). A rich source of corroborated cases of RM is The Recovered Memory Project (Cheit, 1998a), an internet-based archive of over 100 cases for which the proof ranges from very strong to circumstantial. "To be included in the archive, a case must involve a traumatic event that was not remembered in the time shortly after it occurred, was recalled later in life, and has subsequently been corroborated in a meaningful fashion. The vast majority of the cases in the archive involve child sexual abuse because litigation over such claims is one of the only ways that recovered memories tend to result in public disclosure and subsequent analysis" (Cheit, 1998b, p. 143).

\section{Summary of Findings}

Amidst the profusion of studies and opinions it is useful to note Brewin (1998) on RM research: "Another pitfall involves assumptions about what methods are most scientific. . . all designs have their limitations. Rather than setting up one design as the best and basing conclusions on one subset of studies, it is much sounder to consider the evidence from studies utilizing a variety of designs with weaknesses that preferably do not overlap" (p. 216). From the empirical data the following conclusions may be drawn.

It is difficult to find a study in which evidence of amnesia is not found. Recovered memories for either single incident CSA or across multiple incidents of CSA were found in $14 \%-80 \%$ of the populations studied with, generally, higher figures for patient samples. Some sort of corroboration of abuse was later acquired in a significant proportion of subjects in some of the studies (Dalenberg, 1996; Feldman-Summers \& Pope, 1994; Grassian \& Holtzen, 1996, as cited in DePrince et al., 2012), whereas corroboration was inherent in prospective and most case studies. The degree of forgetting greatly varies from total amnesia to some remembering (Crowley, 2007; Fivush \& Edwards, 2004; Gold et al., 1999). Contrary to critics' assertions, many individuals recall previously unavailable memories of CSA 
in non-treatment settings (Elliott, 1997; Wilsnack, Wonderlich, Kristjanson, Vogeltanz-Holm, \& Wilsnack, 2002).

The consensus position regarding the accuracy of recovered memories from examining its now considerable literature base is that:

- whether memories are recovered or continuous may have no bearing at all on their accuracy;

- recovered memories may be true;

- recovered memories may be false;

- recovered memories may vary in their degree of accuracy, ranging from largely accurate to entirely false with many gradations in between;

- irrespective of the nature of retrieval, recovered memories may be true, false or a mix of both.

A number of organizations have published position statements on recovered memories, which include these excerpts (see also Dalenberg, 2006; Middleton et al., 2005):

- "Children and adolescents who have been abused cope with the trauma by using a variety of psychological mechanisms, in some instances, their coping mechanisms result in a lack of conscious awareness of the abuse for varying periods of time" (American Psychiatric Association, 1993, pp.154).

- "Research indicates that some survivors of abuse do not remember, at least temporarily, having been abused" (The American Medical Society's Report on Memories of Childhood Abuse, 1994, p.1).

- "It is possible for memories of abuse that have been forgotten for a long time to be remembered" (The American Psychological Association: Working Group on Investigation of Memories of Childhood Abuse, 1996, p. 933).

- "There is no doubt that people can and do experience the recovery of memories of previously nonremembered childhood sexual abuse" (paper arising from a NATO sponsored consensus meeting on trauma and memory, Lindsay \& Briere, 1997, p. 631).

- "Traumatic memories may be forgotten, then remembered at some later time" (International Society for Traumatic Stress Studies, 1998, p. 15). 
- Emphasizing the extent of physical and sexual abuse of children, and the harmful nature of such abuses: "Memory of such abusive experiences may be absent for considerable and varied periods of life and may be recalled under any of a variety of circumstances, including as a vicissitude of undergoing psychiatric treatment for (at least initially) apparently unrelated reasons" (Royal Australian and New Zealand College of Psychiatry, Clinical Memorandum \#17: Guidelines for psychiatrists dealing with repressed traumatic memories, May 2005).

\section{CONCLUSION}

Brown et al. (1998) have referred to the most widely divergent positions on recovered memories of child sexual abuse as the extreme trauma accuracy position and the extreme false memory position. Advocates of the former (mainly lay authors) argue that recovered memories are pristine, immune from the distortion rendered by the reconstructive nature of all long-term memory (Bass \& Davis, 1988). Advocates of the latter argue that recovered memories are virtually never true (Ofshe \& Watters, 1994); a less extreme position is ostensibly taken by Otgaar et al., (2019) who argue: "The recovery of a purportedly long-forgotten trauma is less plausible in light of everything that we know about traumatic memories" (p. 1074). Such views may dominate and overshadow the views of researchers and clinicians who, while disagreeing as to prevalence of the phenomena and likely mechanisms, concede that both RM and false memory are possible. However, as noted by DePrince et al. (2012): "One of the genuinely positive results of the so-called memory wars has been the flourishing of solid research on forgetting, misremembering, and remembering abuse" (p. 228). This research will be critically reviewed in the second and third articles.

\section{REFERENCES}

Alpert, J. L., Brown, L. S., Ceci, S. J., Courtois, C.A., Loftus, E. F., \& Ornstein, P.A. (1996). Working group on investigation of memories of childhood abuse: Final report. Washington DC: American Psychological Association.

American Psychiatric Association. (1980). Diagnostic and statistical manual of mental disorders, $3^{\text {rd }}$ ed. (DSM-III). Washington DC: American Psychiatric Association.

Bass, E., \& Davis, L. (1988). The courage to heal: A guide for women survivors of child sexual abuse. New York, NY: Harper \& Row.

Beckett, K. (1996). Culture and the politics of signification: The case of child sexual abuse. Social Problems, 43(1), 57-75. https://doi.org/10.2307/3096894

Bradburn, N. M., Rips, L. J., \& Shevell, S. K. (1987). Answering autobiographical questions: The impact of memory and inference on surveys. Science, 236(4798), 157-161. https://doi.org/10.1126/science.3563494 
Brewin, C. R. (1998). Commentary: Questionable validity of 'dissociative amnesia' in trauma victims. British Journal of Psychiatry, 172(3), 216-217. https://doi. org/10.1192/s0007125000260327

Brewin, C. R. (2012). A theoretical framework for understanding recovered memory experiences. In R. F. Belli (Ed.), True and false recovered memories: Toward a reconciliation of the debate (pp. 149-173). New York, NY: Springer.

Brown, D. P., Scheflin, A. W., \& Hammond, D. C. (1998). Memory, trauma treatment, and the law: An essential reference on memory for clinicians, researchers, attorneys, and judges. New York, NY: W. W. Norton \& Company.

Brown, D., Scheflin, A. W., \& Whitfield, C. L. (1999). Recovered memories: The current weight of the evidence in science and in the courts. The Journal of Psychiatry E Law, 27(1), 5-156. https:/ / doi.org/10.1177/009318539902700102

Burgess, A. W., Hartman, C. R., \& Baker, T. (1995). Memory presentations of childhood sexual abuse. Journal of Psychosocial Nursing $\mathcal{E}$ Mental Health Services, 33(9) 9-16. https:/ / doi.org/10.3928/0279-3695-19950901-04

Cheit, R. E. (1998a). The recovered memory project. Retrieved from www. recoveredmemory.org

Cheit, R. E. (1998b). Consider this, skeptics of recovered memory. Ethics and Behavior, 8(2), 141-160. https: / / doi.org/10.1207/s15327019eb0802_4

Collin-Vézina, D., Daigneault, I., \& Hébert, M. (2013). Lessons learned from child sexual abuse research: Prevalence, outcomes, and preventive strategies. Child and Adolescent Psychiatry and Mental Health, 7(22), 1-9. https:/ /doi.org/ 10.1186/1753-2000-7-22

Cossins, A. (1997). Recovered memories of child sexual abuse: Fact or fantasy? Judicial Review: Selected Conference Papers: Journal of the Judicial Commission of New South Wales, 3(3), 163-199.

Crowley, M. S. (2007). Memories of childhood sexual abuse: Narrative analyses of types, experiences, and processes of remembering. Journal of Interpersonal Violence, 22(9), 1095-1113. https:/ / doi.org/10.1177/0886260507302879

Dalenberg, C. J. (1996). Accuracy, timing and circumstances of disclosure in therapy of recovered and continuous memories of abuse. The Journal of Psychiatry $\mathcal{E}$ Law, 24(2), 229-275. https:/ / doi.org/10.1177/009318539602400206

Dalenberg, C. (2006). Recovered memory and the Daubert criteria: Recovered memory as professionally tested, peer reviewed, and accepted in the relevant scientific community. Trauma, violence, and Abuse, 7(4), 274-310. https:/ /doi.org/ $10.1177 / 1524838006294572$

DePrince, A. P., Brown, L. S., Cheit, R. E., Freyd, J. J., Gold, S. N., Pezdek, K., \& Quina, K. (2012). Motivated forgetting and misremembering: Perspectives from betrayal trauma theory. In R. F. Belli (Ed.), True and false recovered memories: Toward a reconciliation of the debate (pp. 193-242). New York, NY: Springer.

Elliott, D. M. (1997). Traumatic events: Prevalence and delayed recall in the general population. Journal of Consulting and Clinical Psychology, 65(5), 811-820. https://doi.org/10.1037/0022-006x.65.5.811

Feldman-Summers, S. \& Pope, K. S. (1994). The experience of "forgetting" childhood abuse: A national survey of psychologists. Journal of Consulting and Clinical Psychology, 62(3), 636-639. https://doi.org/10.1037//0022-006x.62.3.636

Finkelhor, D. (1994). Current information on the scope and nature of child sexual abuse. The Future of Children, 4(2), 31-53. https:// doi.org/10.2307/1602522 
Fivush, R., \& Edwards, V. J. (2004). Remembering and forgetting childhood sexual abuse. Journal of Child Sexual Abuse, 13(2), 1-19. https:/ /doi.org/10.1300/ j070v13n02_01

Freyd, J. J. (1998). Science in the memory debate. Ethics E Behavior, 8(2), 101-113. https://doi.org/10.1207/s15327019eb0802_1

Ghetti, S., Edelstein, R. S., Goodman, G. S., Cordòn, I. M., Quas, J. A., Alexander, K. W., Redlich, A. D., \& Jones, D. P. H. (2006). What can subjective forgetting tell us about memory for childhood trauma? Memory \& Cognition, 34(5), 10111025. https://doi.org/10.3758/bf03193248

Gleaves, D. H., \& Freyd, J. J. (1997). Questioning additional claims about the false memory syndrome epidemic. American Psychologist, 52(9), 993-994. https: / / doi.org/10.1037//0003-066x.52.9.993

Gold, S. N., Hughes, D. M., \& Swingle, J. M. (1999). Degrees of memory of childhood sexual abuse among women survivors in therapy. Journal of Family Violence, 14(1), 35-46. https:/ / doi.org/10.1023/A:1022813925852

Goldfeld, A. E., Mollica, R. F., Pesavento, B. H., \& Faraone, S. V. (1988). The physical and psychological sequelae of torture: symptomatology and diagnosis. Journal of the American Medical Association, 259(18), 2725-2729. http:/ /dx.doi.org/ 10.1001/jama.1988.03720180051032

Goodman, G. S., Ghetti, S., Quas, J. A., Edelstein, R. S., Alexander, K. W., Redlich, A. D., Cordon, I. M., \& Jones, D. P. H. (2003). A prospective study of memory for child sexual abuse: New findings relevant to the repressed-memory controversy. Psychological Science, 14(2), 113-118. https://doi.org/10.1111/14679280.01428

Grinker, R. R., \& Spiegel, J. P. (1945). Men under stress. Philadelphia, PA: Blakiston.

Henry, B., Moffitt, T. E., Caspi, A., Langley, J., \& Silva, P. A. (1994). On the "Remembrance of Things Past": A longitudinal evaluation of the retrospective method. Psychological Assessment, 6(2), 92-101. https://doi.org/10.1037/1040-3590.6. 2.92

Holmes, D. S. (1990). The evidence for repression: An examination of sixty years of research. In J. L. Singer (Ed.), Repression and dissociation: Implications for personality theory, psychopathology and health (pp. 85-102). Chicago, IL: University of Chicago Press.

Kardiner, A. (1941). The traumatic neuroses of war. New York, NY: Paul B. Hoeber.

Kinzie, J. D. (1993). Posttraumatic effects and their treatment among Southeast Asian refugees. In J. P. Wilson \& B. Raphael (Eds.), International handbook of traumatic stress syndromes (pp. 311-319). New York, NY: Plenum.

Kuch, K., \& Cox, B. (1992). Symptoms of PTSD in 124 survivors of the holocaust. American Journal of Psychiatry, 149(3), 337-340. https: / / doi.org/10.1176/ ajp.149.3.337

Lindsay, D. S., \& Briere, J. (1997). The controversy regarding recovered memories of childhood sexual abuse: Pitfalls, bridges, and future directions. Journal of Interpersonal Violence, 12(5), 631-647. https://doi.org/10.1177/ 088626097012005002

Loftus, E. F. (1975). Leading questions and the eyewitness report. Cognitive Psychology, 7(4), 560-572. https:/ / doi.org/10.1016/0010-0285(75)90023-7 
MacMillan, H. L., Jamieson, E., \& Walsh, C. A. (2003). Reported contact with child protection services among those reporting child physical and sexual abuse: Results from a community survey. Child Abuse \& Neglect, 27(12), 1397-1408. https://doi.org/10.1016/j.chiabu.2003.06.003

Madakasira, S., \& O’Brien, K. F. (1987). Acute posttraumatic stress disorder in victims of a natural disaster. Journal of Nervous and Mental Disease, 175(5), 286290. https:/ / doi.org/10.1097/00005053-198705000-00008

Masson, J. M. (1984). The assault on truth: Freud's suppression of the seduction theory. New York, NY: Knopf.

Middleton, W. (2015). Tipping points and the accommodation of the abuser: ongoing incestuous abuse during adulthood. International Journal for Crime, Justice and Social Democracy, 4(2), 4-17. https: / / doi.org/10.5204/ijcjsd.v4i2.210

Middleton, W., De Marni Gromer, L., \& Freyd, J. J. (2005). Remembering the past, anticipating a future. Australasian Psychiatry, 13(3), 223-233. https:/ / doi.org/ 10.1111/j.1440-1665.2005.02192.x

Middleton, W., Stavropoulos, P., Dorahy, M. J., Krüger, C., Lewis-Fernández, R., Martínez-Taboas, A., Sar, V., \& Brand, B. (2013). Institutional abuse and societal silence: an emerging global problem. Australian $\mathcal{E}$ New Zealand Journal of Psychiatry, 48(1), 22-25. https:/ / doi.org/10.1177/0004867413514640

Myers, C. S. (1915). A contribution to the study of shell-shock. The Lancet, 185(4772), 316-320. https:/ / doi.org/10.1016/s0140-6736(00)52916-x

Ofshe, R., \& Watters, E. (1994). Making monsters: False memories, psychotherapy, and sexual hysteria. Berkeley, CA: University of California Press.

Otgar, H., Howe, M. L., Patihis, L., Merckelbach, H., Lynn, S. J., Lilienfeld, S. O., \& Loftus, E. F. (2019). The return of the repressed: The persistent and problematic claims of long-forgotten trauma. Perspectives on Psychological Science, 14(6), 1072-1095. https:/ / doi.org/10.1177/1745691619862306

Pérez-Fuentes, G., Olfson, M., Villegas, L., Morcillo, C., Wang, S., \& Blanco, C. (2013). Prevalence and correlates of child sexual abuse: A national study. Comprehensive Psychiatry, 54(1), 16-27. https:/ /doi.org/10.1016/j.comppsych.2012. 05.010

Pope, H. G., Oliva, P. S., \& Hudson, J. I. (1999). Repressed memories: The scientific status. In D. L. Faigman, D. H. Kaye, M. J. Saks \& J. Sanders (Eds.), Modern scientific evidence: The law and science of expert testimony (pp. 115-155). St. Paul, MN: West Group.

Pope, K. S. (1996). Memory, abuse, and science: Questioning claims about the false memory syndrome epidemic. American Psychologist, 51(9), 957-974. https://doi.org/10.1037//0003-066x.51.9.957

Read, J. D. (1997). Memory issues in the diagnosis of unreported trauma. In J. D. \& D. S. Lindsay (Eds.), Recollections of trauma: Scientific evidence and clinical practice (pp. 79-108). New York, NY: Plenum.

Sargant, W., \& Slater, E. (1941). Amnesic syndromes in war. Proceedings of the Royal Society of Medicine, 34(12), 757-764. https://doi.org/10.1177/ 003591574103401202

Schacter, D. L. (1986). Amnesia and crime: How much do we really know? American Psychologist, 41(3), 286-295. https:/ /doi.org/10.1037//0003-066x.41.3.286 
Scheflin, A. W., \& Brown, D. (1996). Repressed memory or dissociative amnesia: What the science says. The Journal of Psychiatry $\mathcal{E}$ Law, 24(2), 143-188. https://doi.org/10.1177/009318539602400203

Schooler, J. W. (1994). Seeking the core: The issues and evidence surrounding recovered accounts of sexual trauma. Consciousness and Cognition, 3(3-4), 452-469. https://doi.org/10.1006/ccog.1994.1026

Schooler, J. W., Ambadar, Z., \& Bendiksen, M. (1997). A cognitive corroborative case study approach for investigating discovered memories of sexual abuse. In J. D. Read \& D. S. Lindsay (Eds.), Recollections of trauma: Scientific research and clinical practice (pp. 379-387). New York, NY: Plenum.

Silberg, J. L. (2013). The child survivor: Healing developmental trauma and dissociation. New York, NY: Routledge.

Sivers, H., Schooler, J. W., \& Freyd, J. J. (2002). Recovered memories. In V. S. Ramachandran (Ed.), Encyclopedia of the human brain (pp. 169-184). San Diego, CA: Academic Press.

Sloutsky, V. M., \& Fisher, A. V. (2004). When development and learning decrease memory: Evidence against category-based induction in children. Psychological Science, 15(8), 553-558. https://doi.org/10.1111/j.0956-7976.2004.00718.x

Thom, D. A., \& Fenton, N. (1920). Amnesias in war cases. American Journal of Psychiatry, 76(4), 437-448. https: / / doi.org/10.1176/ajp.76.4.437

Van der Hart, O., Steele, K., Boon, S., \& Brown, P. (1993). The ttreatment of traumatic memories: synthesis, realization, and integration. Dissociation, 6(2-3), 162-180.

Van der Kolk, B. A. (1987). Psychological trauma. Washington DC: American Psychiatric Press.

Widom, C. S., \& Morris, S. (1997). Accuracy of adult recollections of childhood victimization, part 2: Childhood sexual abuse. Psychological Assessment, 9(1), 34-46. https: / / doi.org/10.1037 / /1040-3590.9.1.34

Wilkinson, C. B. (1983). Aftermath of a disaster: The collapse of the Hyatt Regency Hotel skywalks. American Journal of Psychiatry, 140(9), 1134-1139. https:/ / doi.org/10.1176/ajp.140.9.1134

Williams, L. M. (1995). Recovered memories of abuse in women with documented child sexual victimization histories. Journal of Traumatic Stress, 8(4), 649-673. https:/ / doi.org/10.1002/jts.2490080408

Wilsnack, S. C., Wonderlich, S. A., Kristjanson, A. F., Vogeltanz-Holm, N. D., \& Wilsnack, R. W. (2002). Self-reports of forgetting and remembering childhood sexual abuse in a nationally representative sample of U.S. women. Child Abuse $\mathcal{E}$ Neglect, 26(2), 139-147. https:/ / doi.org/10.1016/s0145-2134(01)00313-1

Wilson, T. D. (2002). Strangers to ourselves: Discovering the adaptive unconscious. Cambridge, MA: Harvard University Press. 